\title{
Relationship between Covid-19 pandemic and firm's performance towards unemployment across countries
}

\author{
Noriza Mohd Saad ${ }^{\text {a }}$ \\ a 1Fakulti Pengurusan dan Perniagaan,Universiti Teknologi MARA Cawangan Kelantan Kampus Machang,Bukit Ilmu, 18500 \\ Machang, Kelantan, Malaysia \\ Email: Norizajasaad78@gmail.com
}

Article History: Received: 10 November 2020; Revised 12 January 2021 Accepted: 27 January 2021; Published online: 5 April 2021

\begin{abstract}
As a result of the consequences of the Covid-19 pandemic, stock market players issued their quick response on how coronavirus has affected the performance of firms whereby most of the affected sectors are airlines, tourism, hotels, transportation and many more. This has led to an increase in the unemployment rate worldwide. Considering this global issue, this study was aimed at investigating the relationship between unemployment with a number of confirmed cases of Covid-19 and firms' performance as well as the controlling factors across seven (7) countries. Secondary data were utilized with the data obtained from Bloomberg and Worldometers website. The dataset for dependent as proxy by unemployment rate and explanatory variables proxies by COVID-19 and firm's performance were then tested using multivariate regression approach. Finally, from the study, it is suggested that an increase in the number of Covid-19 cases will affect business performance as controlled by macroeconomics factors which lead to a significant positive relationship between the unemployment rates in all the countries of this study. This factor may affect the government's decision to implement the Movement Control Order (MCO), for instance by the Malaysian Government. By Covid-19 vaccine development in the market nowadays, hopefully, the spread can be mitigated and firms' performance can return to normalcy to avoid increasing rate of unemployment in the world.
\end{abstract} Keywords: COVID-19; Firm's Performance; Unemployment, Robust Method, Countries

\section{Introduction}

According to the World Health Organization (WHO), by 10 March 2020, Covid-19 had led to more than 110,000 confirmed infections and 4,015 deaths in 110 countries and the numbers are increasing rapidly. Due to this extreme and drastic increase in the figure of confirmed infections and death cases, the WHO declared the Covid-19 as a global pandemic. Subsequent to the WHO's declaration, the cumulative pattern of the number of confirmed Covid-19 cases was shown statistically by Worldometers website on the 2nd of March 2021. There are 115,282,226 confirmed cases (see Figure 1), 91,100,130 recovered cases and 2,560,305 deaths in 221 countries. The Covid-19 pandemic was first identified in China and was reported in Malaysia on the 25th of January 2020. According to Malaysiakini news, based on data from the Ministry of Health Malaysia, the number of Covid-19 cases remained relatively low until a spike in cases was recorded in March 2020. However, within afew weeks thereafter, Malaysia became the country with the highest cumulative number of confirmed Covid-19 infections in South-East Asia at the end of March 2020 and within the month of April 2020.

Beginning from March 15, Malaysia saw a significant increase in active cases. The Prime Minister of Malaysia held a live nationwide telecast on March 16, 2020, at 10:00 PM to announce the decision of the federal government to implement the Movement Control Order (MCO). With the MCO put in place since March 18, 2020, all citizens were prohibited from leaving the country and foreigners also prohibited from entering the country. 


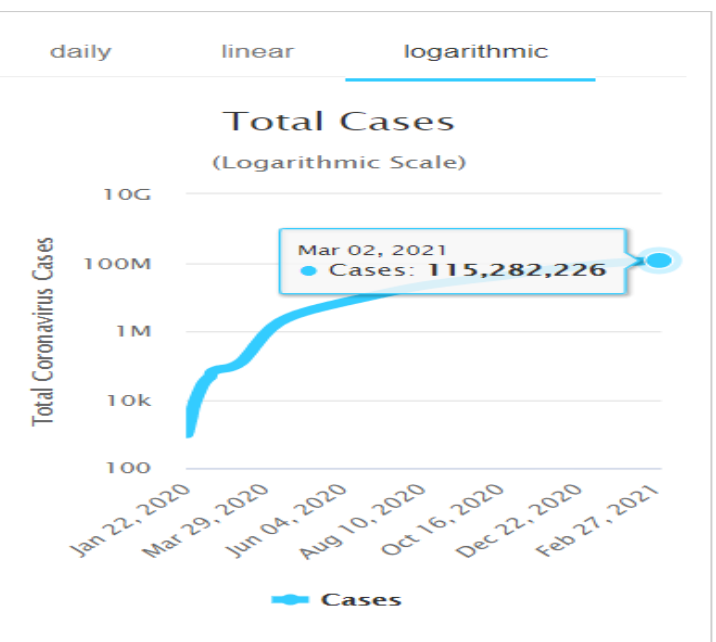

Figure 1: Total number of Covid-19 cases in the world from 22nd of January 2020 to 2nd of March 2021.

Sources: https://www.worldometers.info/coronavirus/. Date retrieved on 3rd March 2021.

In a statement to StarBiz, Bursa Malaysia said the Covid-19 pandemic has evolved from being a health issue to potentially becoming a source of serious economic challenge. In early March, the FBM KLCI along with global markets went through a roller coaster ride, with most markets registering a sharp decline of between 20 to $30 \%$ following the first fallout from the Covid-19 virus. As a result of the consequences of the Covid-19 pandemic, stock market players issued their quick response on how this virus has affected the business performance whereby most of the affected sectors are airlines, tourism, hotels, transportation and many more. However, some of the companies performed better or were still active in the trading at Bursa during this situation because the products offered received high demands such as medicines and pharmaceuticals, and medical companies, utility, information technology services, food and services, gas and water and so on. However, the majority of the stock market players issued their quick response towards their trading performance that affected the stock price performance for listed companies and for non-listed companies. Many small, medium and some large-scale companies had to shut down their businesses which led to the retrenchment of many workers that increased the level of unemployment.

With the MCO put in place since March 18, 2020, all citizens have been prohibited from leaving the country and foreigners also prohibited from entering the country. As a consequence of the Covid-19 pandemic, stock market players issued their quick response on how the coronavirus has affected their business performances whereby most of the affected sectors are airlines, tourism, hotels, transportation and many more. However, stock market regulators are still encouraging the stock market to remain open and they believe that investors can diversify their portfolios towards risk and opportunities. This means that some of the sectors are underperformed but some of them are outperformed.

As claimed by [2], Bursa Malaysia and other emerging stock markets will likely remain a laggard until June 2020, partly due to the outbreak of the Covid-19. The regional markets would be extremely weighed down if the deadly Covid-19 is prolonged. Foreign investors had taken a cautious stance on Bursa particularly, amid the negative headlines emanating from China. Bursa's benchmark FTSE Bursa Malaysia KLCI (FBM KLCI) index ended mixed yesterday amid profit-taking in heavyweights and bargain hunting in small-cap stocks as global markets continued to face uncertainties. The index fell 1.17 points to 1,550.47 from Tuesday's close of $1,551.64[2]$.

In an interdependent and interconnected world, domestic confidence is not usually enough. A well run and profitable company's performance that is stable for human capital and benefit will have to adjust accordingly based on the external environments. For instance, stocks on Malaysia's stock exchange of Bursa Malaysia tumbled during the outbreak as investors sold securities due to the expected economic impact caused by the Covid-19, which along with other emerging stock markets was predicted to remain until June 2020. With China as Malaysia's largest trading partner, the country's economy was directly impacted and economic experts warned that the prolonged virus outbreak could hit hard the country's gross domestic product (GDP).

The country's economic growth may fall below $4 \%$ if the coronavirus outbreak worsens and powerhouses like China and the US fail to halt the slides of their own economies. Countries across the world are already calculating the billions of losses due to the Covid-19 which is the worst flu outbreak in 18 years. Trade-reliant economies like South Korea, Singapore and Malaysia would be severely affected. The three countries had already felt the impact 
of the US-China trade war. China is Malaysia's largest trading partner and the cooling of the second-largest economy in the world would definitely affect the country. The spread of the Covid-19 hits exports, factory output and tourism. A Bloomberg poll of 33 economists estimated Malaysia's average growth of $4.2 \%$ with individual forecasts ranging between 3.7 and $4.7 \%$. One analyst expects that the coronavirus will hive $0.4 \%$ of Malaysia's GDP [4].

Furthermore, China daily on the 19th of February, 2020 reported that Malaysia which also largely relied on tourism and being among the top destinations for Chinese tourists, suffered a stark decline of tourist arrival from Mainland China due to the outbreak with the tourism industry hit the hardest; costing around RM3.37 billion losses until March. Malaysian states are highly dependent on the tourism sector and is the point for Mainland Chinese visitors such as Johor [5] Malacca [6], Penang [7]. These states are among the heavily affected states with hotel bookings and food stalls reported to experience large loss in businesses. These subsequently forced the states to shift their focus to the Southeast Asian market due to the decline of Mainland Chinese tourists [8][9].

Regardless of the large losses incurred by tourism businesses, a number of Malaysians have voiced their concerns over the spread of the virus and urging a ban on travellers from China to the country with some 149,000 in support of the call [10][11]. Aberdeen Standard Investments of Malaysia also predicted the country's currency, the Malaysian ringgit (MYR), to weaken further throughout the local and worldwide outbreak which exacerbate further by unstable local political scenes in the country [12].

With respect to the issues discussed in this introduction part, this study was motivated to investigate the relationship between the unemployment rate with a number of confirmed cases of the Covid-19 pandemic and business firm's performance controlled by GDP growth, inflation rate and interest rate across selected seven countries.

Next, the paper is organized as follows. In the next section, discussion about the issues that arise concerning unemployment and firm's performance, affected by the number of confirmed cases of Covid-19 abroad. The succeeding section explains the data and methodology applied, followed by the results and discussion in the succeeding section. The last section highlights the policy implications of the employment issues which concludes the paper.

\section{Literature Review}

Vast literature reported on firms' performance by many proxies for instance profitability, sales, firm size, leverage level, total asset, shareholdings equity and others. In this study, the firm's performance is limited only to the discussion on the capital structure which consists of the market value of the common share and debt to their proposition with book value of total assets. This performance can be derived as a firm value of the company that is basically based on how companies create their financing structure by issuing equity and bonds to optimize the capital structure for business survival. The survival of the companies especially during the Covid-19 pandemic, with robust macroeconomics situations, is important for a secured job and human capital development. An unstable firm's performance sometimes forces the employees to resign or quit from the job.

Zakaria Firano and Filali Adib Fatine (2020) mentioned that the Covid-19 pandemic could affect all the world economies and the reaction is to strengthen each country on the planet, even to varying degrees. They also highlighted that nowadays, amid a health crisis, countries are thinking of reducing containment constraints in order to seek the optimal circulation of resources and limit the obstacles to the circulation of money. Thus, all countries are seeking to optimise the balance between health and economic well-being, which is quite difficult under the current conditions. Overall, their results show that economic conditions tend to deteriorate, especially as socio-economic relations become closer.

Besides the socio-economic relations, both microeconomic and macroeconomic factors affect the business performance; it is imperative that businesses are aware of these factors in order to reduce the impact of these on future cash flows and profitability. Microeconomic factors such as demand and factors of production are controllable and the effect of which can easily be anticipated and controlled. However, macroeconomic variables especially the unemployment rates, are beyond the control of an organization, therefore, there is the need for businesses to predict the heterogeneous effect of these macroeconomic variables on future corporate performances (Broadstock, Shu, and $\mathrm{Xu}, 2011$ ).

Therefore, the 2020 Covid-19 crisis have spurred research on firms' corporate finance decisions and their macroeconomic implications (Brunnermeier and Krishnamurthy, 2020). A negative correlation was found between the market price of capital and inflation. It does this in an endogenous growth environment where human capital is a major driver of growth by considering the firm value as a proxy by Tobin's $Q$ in the q-inflation-growth relationship. The importance of this is that there is an emerging literature that shows how monetary policy impacts the stock market boom-bust through sticky wages and inflation targeting (Christiano et al, 2007), known as the effect of monetary policy on the stock market via human capital-driven growth. These arguments and findings 
were supported by Parantap, Max \& Joseph (2009) where Tobin's Q with physical adjustment cost is applied to understand the long-run relationship between inflation, $\mathrm{Q}$ and human capital utilization.

Furthermore, based on a pervasive empirical finding from the US economy, inflation is negatively correlated with the normalized market price of capital (Tobin's Q) and growth. A dynamic stochastic general equilibrium model of endogenous growth is developed to explain these stylized facts. In this model, human capital is the principal driver of self-sustained growth. Long run comparative statics analysis suggests that inflation diverts scarce time resource to leisure which lowers human capital utilization. This impacts growth adversely and modulates capital adjustment cost downward resulting in a decline in Tobin's Q. For the short run, a Tobins'Q effect of inflation on growth weakens the negative association between inflation and Q (Parantap, Max \& Joseph, 2009).

Next, Chinedu Francis Egbunike (2018) studied the relationship between macroeconomic factors, firm characteristics and financial performance and reported that there is no significant effect for interest rate and exchange rate, but a significant effect for inflation rate and GDP growth rate on return on assets. Besides, the firm characteristics showed that firm size, leverage and liquidity were significant. A similar finding reported by Tanaka, et. al (2020) reveals three main findings. Firstly, firms' GDP forecasts are associated with their employment, investment, and output growth in the subsequent year. Secondly, over-optimistic and pessimistic forecast errors predict lower profitability and productivity, which is consistent with the model of input choice under uncertainty. Thirdly, the larger and more cyclical firms make forecasts that are closer to professionals, presumably reflecting their higher return to accuracy. Therefore, these results postulated that the impact of the macroeconomic factors towards business performance especially on the firm's value is important to consider in investigating the relationship of the unemployment rate in the country.

In Vietnam, the impact of the Covid-19 lockdown on stock market performance was found to have an adverse impact on the daily increasing number of Covid-19 cases on stock returns whereby the financial sector was hit the hardest, on the Vietnam stock market during the Covid-19 outbreak [14]. In China, transportation, mining, electricity and heating, and environment industries have been adversely affected by the pandemic. However, manufacturing, information technology, education and health-care industries have been resilient to the pandemic [13].

In the United States, the Covid-19 outbreak showed a big impact on energy prices and stock market performance besides weakening in crude oil price. They concluded that the Covid-19 has a significant impact on the global economy since their study covers crude oil price and three US stock indexes: DJI, S\&P 500, and NASDAQ Composite [15].

Further analysis of the US economy revealed that changes in share prices exposed how different industries are affected by Covid-19 on real-time/daily basis. Stock market data does have a few limitations, however, when it comes to measuring the impact of the crisis [16]. Notably, it does not include small firms, firms that are not publicly listed, the third sector or the public sector, which might be affected quite differently. For example, many public sector services have seen an increase in demand. In addition, many of these firms operate internationally, so changes in their share prices will represent the effects not only on the UK economy but also in other markets that they operate in.

The spread of Covid-19, and international measures to contain it, are having a major impact on economic activity in the UK. In this observation, how this impact has varied across industries is described using data on share prices of firms listed on the London Stock Exchange. Also described is, how well-targeted government support for workers and companies is, in light of this. This follows [17] who described the impact on the US and China by looking at changes in share prices. The industries that have been hit the hardest include tourism and leisure (which includes air travel), fossil fuels production and distribution, insurance, retailers (excluding food and drug retailers) and some large manufacturing industries. At the other end of the spectrum, some industries have outperformed the market, including food and drug manufacturers and retailers, utilities, high tech manufacturing and tobacco. Unsurprisingly, firms in medical and biotech research have also outperformed the market (falling by $16 \%$ relative to the overall fall of 35\%). Instead, big changes in share prices occurred from the end of February, in the days following Italy's introduction of a lockdown in Lombardy, with very little change in prices in the period before. The exceptions to this are the gas and water, automotive and parts, and fossil fuel production sectors, where changes in share prices took place steadily over the three-month period, possibly driven by other factors.

The tourism and leisure (excluding air travel) sector stands out as being one of the hardest-hit industries (in terms of seeing a large reduction in relative share price) and having a relatively high share of protection. As the shutdown continues, more capital-intensive firms that are not able to substantially reduce their costs may start to struggle more; this may lead to pressure for further government support. There are likely to be long-run costs to the economy if these firms were forced to shut down and the skills and experience of their workers were lost [17]. 
These series of studies that focus on stock prices highlighted that the market value of the equity reported dynamic performance that affected the firm's value and capital structure of the companies. Even though some of the business sectors are still outperformed, however, most of the companies are affected by this Covid-19 pandemic that affected the economic factors in the country which offer no new job and perform retrenchment program on employees. According to Daskalakis, Balios \& Dalla (2017), the global financial crisis has triggered capital structure dynamic determination regarding how "quickly" companies tend to adjust their capital structure to their long-term targets, in different macroeconomic states. They also found clear differentiations of the effects and the contribution of the firm-specific and the macroeconomic variables between short-term debt and long-term debt ratios, when macroeconomic states change.

In the perspectives of the private sector, Mokhova \& Zinecker (2014) indicated the influence of macroeconomic factors on corporate capital structure in different European countries. The global financial crisis and the European debt crisis show the significance of the country financial stability, the efficiency of fiscal and monetary policies, and their impact on the private sector. Besides, the macroeconomic policies of a country affect the financial performances of the companies and their future sustainable development and growth. They also put stress on the human capital initiates by managers who make their financial decisions according to the source of financing and capital structure based on the company's advantages and disadvantages, i.e. its internal characteristics, and doubtless on the macroeconomic conditions and country specifics, i.e. external factors. The findings show the significance of macroeconomic factors in the decision-making process regarding capital structure and the source of financing.

In relation to the firms' performance and economic factors, (Bastos, Nakamura \& Basso, 2009; Bokpin, 2009; Dincergok \& Yalciner, 2011; Camara, 2012) found that there is a negative and significant relationship between corporate capital structure and GDP (as well as GDP growth). The boost in economy and consequently growth in GDP lead to an increase in companies' profits. According to pecking order theory, companies will prefer internal sources as retained earnings then debt. Other than GDP, the next economic factor needed to be considered is the inflation rate. With respect to this proxy, there are mixed results reported. For instance, inflation has a strong and positive influence on the capital structure (Hanousek \& Shamshur, 2011); inflation does not influence the capital structure (Bastos, Nakamura \& Basso, 2009); inflation haz relationship with market leverage, but no effect on the book leverage (Frank \& Goyal, 2009). Camara (2012) showed that macroeconomic conditions including inflation rate have a significant relationship with capital structure.

In addition, some authors have investigated the influence of different macroeconomic indexes on the corporate capital structure. For instance, Duan, Chik bin. \& Liu (2012) found out that the product market index, legal system index, non-state economic structure index and financial market index are negatively correlated with debt ratio. Moreover, the companies choose short-term loans, if the degree of government intervention is stronger, the efficiency of the product market is higher, and the legal system is robust. And the preferred source of financing is long-term loans if the proportion of the non-state economy is greater and the development of financial sector is higher.

Also focused on capital structure, Kottaridi \& Siourounis (2007) witnessed a significant change in the structure of capital flows to developed as well as developing countries. They provided empirical evidence that a bad liquidity shock increases, investors switch to safer assets but with a pecking order: they seem to damp equities for more bonds and more direct investments. Sadiq, et. al (2020) also claimed that debt in capital structure and firms' performance has a great novelty in reducing market imperfections that improve firms' values. Besides, they confirmed a U-shaped relationship between debt and Tobin's Q in mediation with the country's per capita income. Pervaiz Ahmed Memon et al. (2015) applied pooled OLS and fixed effect regression as estimation techniques and found out that profitability, tangibility, and size of the firm appear to significantly affect debt level across different proxies and different estimation techniques. Interest rate and inflation are significant determinants of debt in fixed effect estimation. Previous study also confirmed the existence of firm specific influence on firm performance.

Based on business globalization and the fierce competition for market share among the companies, it is fundamental for a firm to maintain a high firm performance (Ruhomaun, Saeedi \& Nagavhi (2019). They highlighted that firm performance is considered as an important indicator for investors while making investment decisions since it reflects a firm's overall financial health. Hence, firm performance is influenced by economic factors, macro and microeconomic variables such as exchange rate, interest rate, financial distress and derivatives usage. The study reveals that both interest rate and financial distress have a negative and significant effect on firm performance.

Based on the sample size across countries, Sahin (2018) studied the non-financial companies within the fragile five countries (Turkey, Brazil, South Africa, India and Indonesia) during the period of 2004-2013. The factors affecting capital structure were assessed along with micro and macro variables for these countries. The micro 
variables (firm specific) included in the model were the debt taken in the previous year, firm size, growth, industry debt average, and the tangibility and profitability ratio; GDP growth, inflation and exchange rate change were included in the model as macroeconomic variables. A statistically significant relationship was discovered between the GDP growth rate and the debt ratio only for Turkey for the full period (2004-2013) and for India for the period between 2006 and 2013. On the other hand, a positive relationship was found between the inflation rate and the debt ratio for the general (2004-2013) and post-crisis models. In addition to that, results reported a negative relationship between price to book value and leverage ratio for Turkey and South Africa. However, a positive and statistically significant relationship between expected inflation rate and leverage ratio was found for the model with all countries.

The financing decision of a firm is influenced by both internal (firm specific) and external (macroeconomic) factors. However, the impact of macroeconomic variables on capital structure decisions focused on firm value might be affected by the unemployment rate and is somewhat under-researched particularly in the context of developing countries (Rehman, 2016). However, there are other external determinants of a corporate capital structure which has been studied, e.g; public debt, ban credit, unemployment rate, Tobins' Q, ROA, firm value, capital structure and etc. (Korajczyk \& Levy, 2003; Bastos, Nakamura \& Basso, 2009; Bokpin, 2009; Sett \& Sarkhel, 2010; Duan, Chik \& Liu, 2012; Camara, 2012, Jinji, Zhang \& Haruna, 2019; Sadiq,et. al., 2020; Tanaka, et. al, 2020; Yang \& Gan, 2021.

The latest study on the Covid-19 vaccine done by Shrotri, Swinnen, Kampmann \& Parker (2021) hopefully can treat and eliminate the pandemic for spreading and recovery processes by mitigating the issue in increasing unemployment rate at the global level. Here, non-pharmaceutical interventions have been the mainstay of epidemic control to date, vaccination is likely to constitute the definitive, long-term defence strategy against SARS-CoV-2 morbidity, mortality, and transmission, offering the best hope of a return to normal life.

\section{Data and Methodology}

Secondary data are utilized for; unemployment rate as a dependent variable and the number of confirmed cases of Covid-19 and firms' performance as a proxy by firm value as an independent variable and macroeconomics factors like GDP growth, inflation rate and interest rate as controlling variables. The study period started from January 15, 2020, up to January 15, 2021, limited only to the Covid-19 pandemic spread issue. The data were gathered from Bloomberg for all listed companies in seven countries under five main sectors (Consumer Discretionary, energy, industrial, information technology and real estate) for data availability since most of the listed firms still do not published the current data in year 2020 (see Table 1). Therefore, the unbalanced panel data are reported. With regards to the Covid-19, the data were obtained from Worldometers website.

Table 1: Sample Size of the Study

\begin{tabular}{|c|c|c|c|}
\hline Country & $\begin{array}{c}\mathrm{F} \\
\text { req }\end{array}$ & $\%$ & Cum. \\
\hline $\begin{array}{l}\text { Hong } \\
\text { Kong }\end{array}$ & $03^{2}$ & 10.42 & 10.42 \\
\hline Japan & $358^{1}$ & 69.68 & 80.09 \\
\hline Malaysia & $38^{2}$ & 12.21 & 92.3 \\
\hline $\begin{array}{l}\text { Philippin } \\
\text { es }\end{array}$ & 5 & 0.26 & 92.56 \\
\hline $\mathrm{e}^{\text {Singapor }}$ & $29^{1}$ & 6.62 & 99.18 \\
\hline Thailand & $3^{1}$ & 0.67 & 99.85 \\
\hline Vietnam & 3 & 0.15 & 100 \\
\hline
\end{tabular}

Next, the multiple regression for such relationship is represented by model equation, ordinary least square (OLS) as follows:

UEmployit $=\alpha+$ COVID $-19 i t+F V+E C O+\varepsilon i t \ldots$. OLS (1) 
where UEmploy stands for the unemployment rate, the time period is denoted by the subscript $\mathrm{t}(\mathrm{t}=1$ year, 2020 which refers to the year Covid-19 emerged); sectors are denoted by the subscript $\mathrm{i}(\mathrm{I}=1 \ldots . .5, \mathrm{~N}=1 \ldots 7$ countries, 1...1949 companies); Covid-19 refers to the number of confirmed cases; FV refers to the firms' performance as proxy by firm value; ECO represents macroeconomic factors which consisted of GDP growth, inflation rate and interest rate; $\alpha$ represents intercept error term.

\section{Results and Discussion}

The study considered seven countries with 1949 listed companies traded in each country with the total number of confirmed covid-19 cases respectively as shown in figure 2. The highest number of Covid-19 is from Philippines and the lowest is Hong Kong based on study period. From these statistics we can see that is there any relationship between this number of Covid-19 cases with the unemployment rate as shown in figure 3 . By comparing direct approach using these bar graph, the Philippines also shown at the highest unemployment rate with 10.43 percent. Thus, it was significant for this study to further research and validate the dataset by using statistical approach, OLS.

The data are normal distributed as reported by skewness and kurtosis statistics whereby the data are in between +/- 3.0. These results are supported by the pairwise correlation as shown in table 3, there are no multicollinearity issue among the variables reported by the $\mathrm{F}$ value is less than 0.7 . With respect to the mean, minimum and maximum value for all the proxies (see table 2), the mean for the unemployment across country is 3.31 percent shows quite far different with the highest record at 10.43 percent for year 2020 whereas at minimum of 2 percent. As for firms' performance, mean value shows at 1.09 percent with minimum and maximum at 0.09 and 11.72 respectively. This implies that some of the companies in the country are still performed better even though during Covid-19 pandemic. With regards to the macroeconomic performance, the conditions are not stable for year 2020 as postulated by mean value of negative GDP growth and inflation rate as well as very low interest rate which can't help to boost the economy at global.

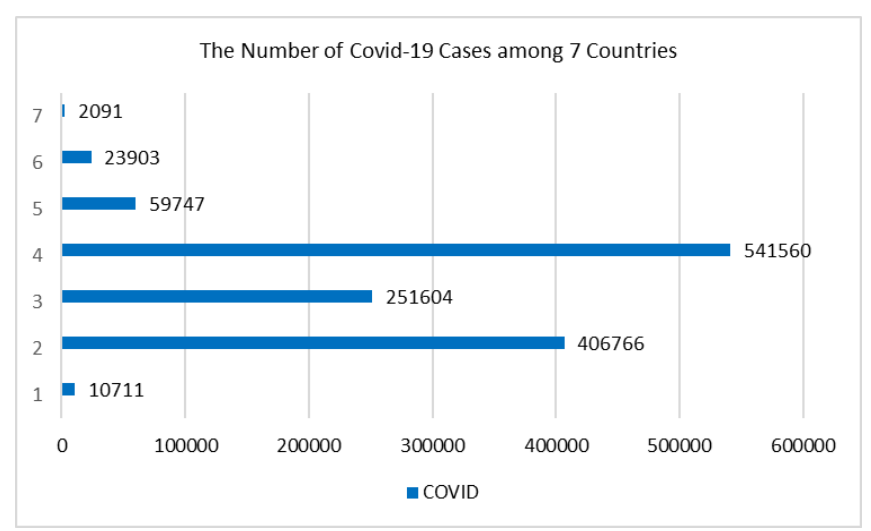

Figure 2: The Number of Covid-19 Cases among 7 Countries; where 1= Hong Kong; 2= Japan; 3= Malaysia; 4= Philippines; $5=$ Singapore; $6=$ Thailand; $7=$ Vietnam.

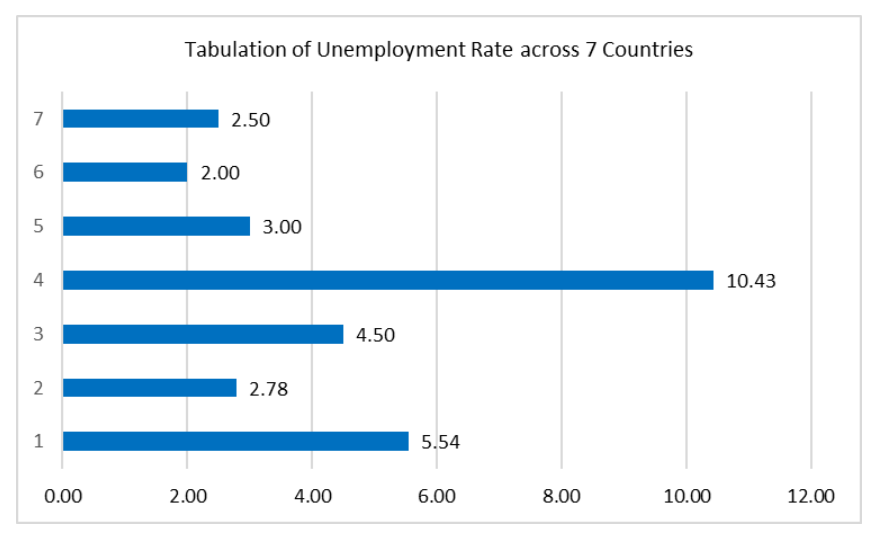

Figure 3: The Unemployment Rate across Countries

Table 2: Descriptive Statistics and Normality Tests Results 


\begin{tabular}{|l|c|c|c|c|c|c|c|}
\hline Variable & Obs & Mean & Std Dev & Min & Max & Skewness & Kurtosis \\
\hline Country & 1,949 & 2.26 & 0.96 & 1 & 7 & 0.00 & 0.00 \\
\hline Sector & 1,949 & 2.81 & 1.32 & 1 & 5 & 0.02 & 0.00 \\
\hline Unemploy & 1,949 & 3.31 & 1.02 & 2 & 10.43 & 0.00 & 0.00 \\
\hline Firm Value & 1,949 & 1.09 & 0.86 & 0.09 & 11.72 & 0.00 & 0.00 \\
\hline Covid & 1,949 & 320,768 & 145,395 & 2091 & 541,560 & 0.00 & 0.34 \\
\hline GDP & 1,949 & -5.48 & 0.49 & -9.5 & 2.91 & 0.00 & 0.00 \\
\hline Inflation & 1,949 & -0.11 & 0.44 & 1.14 & 3.18 & 0.01 & 0.00 \\
\hline Interest Rate & 1,949 & 0.29 & 0.61 & -0.03 & 4 & 0.00 & 0.00 \\
\hline
\end{tabular}

Table 3: Pairwise Correlation Results

\begin{tabular}{|c|c|c|c|c|c|c|c|c|}
\hline Variable & Country & Sector & Unemploy & FV & Covid & GDP & \multicolumn{2}{|c|}{ Inflation Interest } \\
\hline Country & 1.00 & & & & & & & \\
\hline Sector & 0.06 & 1.00 & & & & & & \\
\hline Unemploy & -0.16 & 0.03 & 1.00 & & & & & \\
\hline Firm Value & 0.05 & 0.02 & 0.07 & 1.00 & & & & \\
\hline Covid & 0.27 & 0.05 & -0.69 & 0.07 & 1.00 & & & \\
\hline GDP & -0.03 & -0.01 & -0.66 & 0.05 & 0.48 & 1.00 & & \\
\hline Inflation & -0.39 & -0.08 & -0.08 & 0.05 & 0.05 & 0.21 & 1.00 & \\
\hline Interest & 0.39 & 0.08 & 0.65 & -0.08 & -0.47 & -0.29 & -0.63 & 1.00 \\
\hline
\end{tabular}

Next, based on the results presented in Table 4, unbalanced panel data were applied for the tests indicate an unequal number of observations, $\mathrm{N}$ which covered the pooled ordinary least square (OLS) model. R-square is reported for the model estimation of regression in order to investigate the percentage of relationship from the number of Covid-19 cases and firm value as explanatory variation in explaining the level of unemployment rate controlled by macroeconomics factors in each country. The R-square and adjusted R-square results also revealed a very satisfactory and strongly acceptable value for almost 87.5 percent. This implies that unemployment rate has about 87.5 percent affected by the Covid-19 cases since the p value has shown a significant at 99 percent confident level at significant controlling variables to all. However, the performance of companies shows insignificant result as similar as industry sector since this pandemic spread worldwide.

Table 4: Multivariate Regression Results

\begin{tabular}{|l|c|c|c|}
\hline Variable & Coeff & t & P \\
\hline Intercept & -2.386 & -19.25 & 0.000 \\
\hline Sector & -0.002 & -0.39 & 0.696 \\
\hline Firm Value & 0.005 & 0.48 & 0.633 \\
\hline Covid & -0.000 & -8.85 & 0.000 \\
\hline GDP & -1.033 & -52.54 & 0.000 \\
\hline Inflation & 1.237 & 63.89 & 0.000 \\
\hline Interest & 1.354 & 63.89 & 0.000 \\
\hline R Sq. & \multicolumn{3}{|c|}{$87.46 \%$} \\
\hline Adj. R Sq. & \multicolumn{3}{|c}{$87.42 \%$} \\
\hline F-Value & $294.169 * * *$ \\
\hline
\end{tabular}

\section{Discussion And Conclusion}

Covid-19 vaccine recently discover hopefully can treat and eliminate the pandemic for spreading and recovery processes by mitigating the issue in increasing unemployment rate at the global level. The finding of this study concludes that Covid-19 have a relationship towards unemployment in seven countries especially Philippines followed by Hong Kong and Malaysia. Since this study also consider firm value as a firms' performance proxy, therefore the study provides a practical outcome to a government and stock market player in across countries as well as stakeholders particularly for the future strategize planning while facing any pandemic event that most probably will happen again and again. Besides, the findings benefited stakeholders who will be able to provide justifications, by considering the risk and opportunities (possible gain in abnormal returns) in the trading market, and who will be able to forecast the movement of share price by identifying its significant reaction to certain sectors, and who will be able to make recommendations and provide inputs to government on risks and opportunities in business performance. Thus, this study can provide a reference to stakeholders on the significant association between unemployment rate and COVID-19 pandemic spreads and firms' performance by considering the different macroeconomics factors states. 


\section{References}

Say T.L (2020), Bursa Malaysia getting feedback on shorter trading hours Market, The Star, 1st April 2020.

Yusof, A (2020). Coronavirus may bug Bursa, other emerging markets". New Straits Times. (30 January 2020). Archived from the original on 23 February 2020. Retrieved 22 February 2020.

Ralph, J (2020)"Coronavirus Strikes Tourism, Factories, Consumption around Southeast Asia". Voice of America. (12 February 2020). Archived from the original on 22 February 2020. Retrieved 22 February 2020.

Alifah Z \& Hussein S (20 February 2020). "Prolonged Covid-19 may hit Malaysia's GDP hard". The Malaysian Reserve. Archived from the original on 21 February 2020. Retrieved 22 February 2020.

D'Silva, V. (17 February 2020). "Johor tourism sector suffers severe Covid-19 fallout, seeks govt help". New Straits Times. Archived from the original on 22 February 2020. Retrieved 22 February 2020. (D'Silva, 2020),

Aziz, A\& Naharul, M.A (14 February 2020). "Melaka's tourist footfall drops, thousands of bookings cancelled". The Malaysian Reserve. Archived from the original on 22 February 2020. Retrieved 22 February 2020 (Sekaran, 2020)

Sekaran, R. (11 February 2020). "Penang tourism feeling the effects". The Star. Archived from the original on 22 February 2020. Retrieved 22 February 2020.

Chinese tourists". The Star. Archived from the original on 22 February 2020. Retrieved 22 February 2020

COVID-19 outbreak". CNA. Archived from the original on 22 February 2020. Retrieved 22 February 2020.

Solhi, F (26 January 2020). "Some Malaysians calling for ban on Chinese tourists". New Straits Times. Archived from the original on 23 February 2020. Retrieved 23 February 2020.

Dzulkifly, D (13 March 2020). "Muhyiddin: Tourism industry hit hardest by Covid-19, faces RM3.37b loss". The Malay Mail. Archived from the original on 14 March 2020. Retrieved 14 March2020.

Eustance H \& Yen N.L. (26 February 2020). "Malaysian ringgit set to weaken further as political chaos and coronavirus take hold, says Aberdeen". CNBC. Archived from the original on 28 February 2020. Retrieved 26 February 2020.

He, P., Sun Y., \& Zhang Y., ORCID Icon \&Tao Li (2020). COVID-19's Impact on Stock Prices Across Different Sectors-An Event Study Based on the Chinese Stock Market, Emerging Markets Finance and Trade, Volume 56, 2020 - Issue 10: Special Issue: Research on Pandemics, Pages 2198-2212 | Published online: 25 Jul 2020

Anh, D.L.T. and Gan, C. (2020), "The impact of the COVID-19 lockdown on stock market performance: evidence from Vietnam", Journal of Economic Studies, Vol. ahead-of-print No. ahead-of-print. https://doi.org/10.1108/JES-06-2020-0312.

Štifanić, D. Musulin, J., Miočević, A., Šegota, S.B.,Šubić, R. \& Car, A., "Impact of COVID-19 on Forecasting Stock Prices: An Integration of Stationary Wavelet Transform and Bidirectional Long Short-Term Memory", Complexity, vol. 2020, Article ID 1846926, 12 pages, 2020. https://doi.org/10.1155/2020/1846926

Niels Joachim, G., \&Koijen.R 'Coronavirus: Impact on Stock Prices and Growth Expectations'. Becker Friedman Institute for Economics WP 2020-22, 24 March 2020.

Stefano,R.,\& Wagne,W (2020) 'What the stock market tells us about the consequences of COVID-19'. VoxEU, https://voxeu.org/article/what-stock-market-tells-us-about-consequences-covid-19, 12 March 2020.

Markus Brunnermeier, Arvind Krishnamurthy (2020). The Macroeconomics of Corporate Debt, The Review of Corporate Finance Studies, Volume 9, Issue 3, November 2020, Pages 656-665, https://doi.org/10.1093/rcfs/cfaa015

Zia Ur Rehman (2016). Impact of Macroeconomic Variables on Capital Structure Choice: A Case of Textile Industry of Pakistan. The Pakistan Development Review 55:3 (Autumn 2016) pp. 227-239.

Madhumita Shrotri, Tui Swinnen, Beate Kampmann \& Edward P K Parker (2021). An interactive website tracking COVID-19 vaccine development. Open Access Published : March 02, 2021 DOI:https://doi.org/10.1016/S2214-109X(21)00043-7

Osman Sahin (2018). Firm Specific and Macroeconomic Determinants of Capital Structure: Evidence from Fragile Five Countries. Eurasian Journal of Business and Economics 2018, 11(22), 59-81.

Mohammad Ashfaq Ruhomaun, Mitra Saeedi, Navaz Nagavhi (2019). The Effects of Selected Macro \& Micro Economic Variables on Firm Performance for Listed Firms in the Industrial Products Sector in Malaysia. International Journal of Recent Technology and Engineering (IJRTE) ISSN: 2278-3075, Volume-7 Issue-5S, January 2019

Misbah Sadiq, Sheikh Usman Yousaf, Muhammad Khalid Anser, Haroon ur Rashid Khan, Sriyanto Sriyanto, Khalid Zaman, Duong Van Tu, Siti Nisrin Mohd Anis (2020). The role of debt financing in the relationship between capital structure, firm's value, and macroeconomic factors: To throw caution to the wind. The Quarterly Review of Economics and Finance, https://doi.org/10.1016/j.qref.2020.11.001.

Nikolaos Daskalakis, Dimitrios Balios, Violetta Dalla (2017). The behaviour of SMEs' capital structure determinants in different macroeconomic states. Journal of Corporate Finance, Volume 46, 2017, Pages 248260. https://doi.org/10.1016/j.jcorpfin.2017.07.005. 
Natalia Mokhova and Marek Zinecker (2014). Procedia - Social and Behavioral Sciences 110 ( 2014 ) 530 540

Katagiri, Mitsuru, "A Macroeconomic Approach to a Firm's Capital Structure" (2011). Publicly Accessible Penn Dissertations. 399. http://repository.upenn.edu/edissertations/399

Pervaiz Ahmed Memon et al. / Procedia - Social and Behavioral Sciences 172 ( 2015 ) 200 - 207.

C. Kottaridi, G. Siourounis / Mathematical and Computer Modelling 46 (2007) 151-162.

Zakaria Firano \& Filali Adib Fatine (2020). The COVID-19: macroeconomics scenarii and role of containment in Morocco. One Health 10. https://doi.org/10.1016/j.onehlt.2020.100152

Mohammed Issah \& Samuel Antwi | David McMillan (Reviewing Editor) (2017) Role of macroeconomic variables on firms' performance: Evidence from the UK, Cogent Economics \& Finance, 5:1, DOI: $10.1080 / 23322039.2017 .1405581$

Naoto Jinji, Xingyuan Zhang, Shoji Haruna (2019). Does a firm with higher Tobin's q prefer foreign direct investment to foreign outsourcing?. The North American Journal of Economics and Finance, Volume 50, https://doi.org/10.1016/j.najef.2019.101044.

Misbah Sadiq, Sheikh Usman Yousaf, Muhammad Khalid Anser, Haroon ur Rashid Khan, Sriyanto Sriyanto, Khalid Zaman, Duong Van Tu, Siti Nisrin Mohd Anis (2020).The role of debt financing in the relationship between capital structure, firm's value, and macroeconomic factors: To throw caution to the wind. The Quarterly Review of Economics and Finance, 2020. https://doi.org/10.1016/j.qref.2020.11.001.

Bo Yang, Liu Gan (2021). Contingent capital, Tobin's q and corporate capital structure, The North American Journal of Economics and Finance, Volume 55, 2021. https://doi.org/10.1016/j.najef.2020.101305. (https://www.sciencedirect.com/science/article/pii/S1062940820301935)

Mari Tanaka, Nicholas Bloom, Joel M. David, Maiko Koga (2020). Firm performance and macro forecast accuracy. Journal of Monetary Economics 114 (2020) 26-41.

\section{AUTHORS PROFILE}

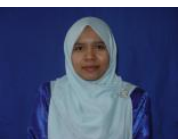

Dr. Noriza Mohd Saad

She is an Assoc. Prof in Business \& Management at Universiti Teknologi MARA Cawangan Kelantan, Machang. She obtained her Bachelor of Finance (Hons) from Universiti Teknologi MARA in 2001, MBA from Universiti Utara Malaysia in 2002 and graduated from Universiti Teknologi MARA in 2017 with a Ph.D in Accountancy. Her areas of research are Islamic capital market, corporate governance, capital structure, business financial performance, tariff optimization and sukuk market. 